\title{
Effects of neighboring woody plants on target trees with emphasis on effects of understorey shrubs on overstorey physiology in forest communities: a mini-review
}

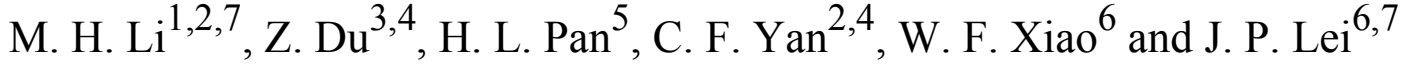 \\ ${ }^{1}$ Ecophysiology Group, Swiss Federal Research Institute WSL, Zuercherstrasse 111, CH-8903 Birmensdorf, \\ Switzerland \\ ${ }^{2}$ State Key Laboratory of Forest and Soil Ecology, Institute of Applied Ecology, Chinese Academy of Sciences, \\ Shenyang 110164, China \\ ${ }^{3}$ Institute of Mountain Hazards and Environment, Chinese Academy of Sciences, Chengdu 610041, China \\ ${ }_{5}^{4}$ Graduate University of Chinese Academy of Sciences, Beijing 100049, China \\ ${ }^{5}$ Sichuan Academy of Forestry, Chengdu 610081, China \\ ${ }^{6}$ Chinese Academy of Forestry, Beijing 100091, China \\ ${ }^{7}$ Corresponding author: Email: maihe.li@wsl.ch
}

Keywords: Carbon balance, Competition, Forest plantation management, Nitrogen, Non-structural carbohydrates, Overstorey-understorey interaction, Tree-shrub interaction, Understorey removal.

\begin{abstract}
Plant-plant interaction plays a key role in regulating the composition and structure of communities and ecosystems. Studies of plant-plant interactions in forest ecosystems have mainly concentrated on growth effects of neighboring plants on target trees. Physiological effects of neighboring plants on target trees, in particular understorey effects on physiology of overstorey trees, have received less attention. It is still unclear what is the physiological mechanisms underlying positive growth effects of understorey removal, although understorey removal has been applied to improve the wood production for hundreds of years worldwide. Only $17.5 \%$ of published works dealt with understorey-overstorey interactions and only a few of those researched the understorey effects on the physiology of overstorey trees. Case studies indicated that overstorey Abies faxoniana trees grown with different understorey shrubs showed significantly different levels of tissue nitrogen and mobile carbohydrates. Removal experiment showed that nitrogen and mobile carbohydrates concentrations in Cunninghamia lanceolata trees grown in the absence of understorey shrubs differed significantly (pure stand $>$ mixture) with those in trees grown in the presence of understorey shrubs, in particular during the dry season. This review highlighted that the neighboring woody plants affect Cand N-physiology in overstorey trees. These effects may be mainly resulted from underground competition for soil water rather than for other resources as the effects were more pronounced during the dry season. The present review suggests that positive effects of neighboring removal (e.g., understorey removal, thinning) on overstorey trees can be expected more rapidly and strongly in stressful area (e.g., low rainfall, nutrient-poor site) than in areas with optimal growth conditions. Hence, ecophysiology-based management strategies for dealing with neighboring plants in forest ecosystems should take into account: 1) site conditions, 2) timing, duration and frequency of management practices, and 3) species-specific properties and other aspects such as biodiversity conservation and soil erosion.
\end{abstract}

Abbreviation: NSC-Non-Structural Carbohydrate.

\section{Introduction}

A fundamental question of how plant species stably coexist in a community is still waiting for conclusive answers in plant community ecology (Silvertown 2004). Coexisting plants interact in many different ways, and plant-plant interaction plays a key role in regulating and determining the composition, functioning and productivity of plant communities and ecosystems (Brooker 2006).

Plants coexist in nature. The co-existing plants in a community may have allelopathic phenomena, and compete for light, nutrients, space, pollinators, and water, but at the same time protect one another from the impacts of herbivores, potential competitors or extremes of climate, and provide additional resources through canopy leaching, microbial en- hancement, mycorrhizal networks and hydraulic lift (Barot 2004, Balandier et al. 2006, Dudareva et al. 2006, Brooker et al. 2008, van der Heijden and Horton 2009). These interactions will further influence the individual physiological activity determining the growth performance at individual and community level.

Plant-plant interaction occurs in either monoculture (intraspecific) or mixed culture (interspecific and intraspecific). The co-existing individuals of the same species (monoculture) have the same or similar architecture and resource requirement (Keddy 1989, Grace and Tilman 1990). Stable coexistence of different species (mixture) may require them to occupy different niches (Gause 1934, Wilson 1990, Silvertown 2004), in order to acquire resources from external pools (Kuppers 1985, Tremmel and Bazzaz 1995, Grams et al. 
2002, Kozovits et al. 2005). These resources are invested to determine the size, morphology, and physiological activity of a plant, which further influences a plant's physiological ability to explore the environment for resource availability (Kuppers 1984, Umeki 1995, Suzuki 2002), and determines the process of resource acquisition (Curran et al. 1999).

Plant size and architecture determine the positioning of leaves and fine roots (Kozovits et al. 2005) and biomass partitioning, which may change in response to neighboring plants of the same or other species (Weiner and Fishman 1994, Tremmel and Bazzaz 1995, Aerts 1999, Aphalo et al. 1999). Natural forests, old growth stands, and unmanaged forest plantations are normally multilayer structures with tall- and medium-size trees, shrubs, climbing vines, and ground vegetation. In such forest ecosystems, the coexistence of overstorey and understorey vegetation is sustained (Kume et al. 2003) under overstorey-understorey interactions.

Although understorey vegetation competes sustained with the coexisting overstorey for space and resource, understorey effects on overstorey trees, especially on the overstorey physiology, have received less attention, because understorey, due to the smaller plant size, is not able to shade the coexisting overstorey's green shoots. In particular, no work studied differences in mobile carbohydrates (soluble sugars and starch) in trees growing in the absence and presence of understorey vegetation, although mobile carbohydrates concentrations and the pool size in trees reflect the balance between carbon gain (photosynthesis) and carbon loss (growth and maintenance respiration) and have been widely recognized as a tree's capital for growth (e.g., Li et al. 2002, Körner 2003). Hence, the present paper, unlike other systematic review papers published (Rothe and Binkley 2001, Binkley et al. 2003, Forrester et al. 2006b, Kelty 2006), will focus on the effects of neighboring woody plants on physiology with emphasis on mobile carbohydrates in desired trees. The aim of the present paper is to explore whether removal of neighboring woody plants in particular understorey shrubs can positively influence the overstorey physiology resulting in enhanced availability of nitrogen and mobile carbohydrates in overstorey tissues. In addition, the present paper will contribute to a better understanding of the functional mechanisms of the effects of neighbor removal which has been applied in forest plantations to improve wood productivity for hundreds of years worldwide.

\section{A statistic overview of plant-plant interaction studies in forest ecosystems}

Studies related to plant-plant interactions in forest ecosystems have traditionally concentrated on effects of associated plants/trees on growth (height, diameter, and biomass growth, and stand development and productivity) (46.1\%, Fig. 1), followed by tissue nutrients (17.0\%, Fig. 1; mainly macronutrients), belowground system including soil nutrients and soil water availability, and microclimate $(11.2 \%$, Fig. 1), gas exchange and water use efficiency (8.2\%, Fig. 1)

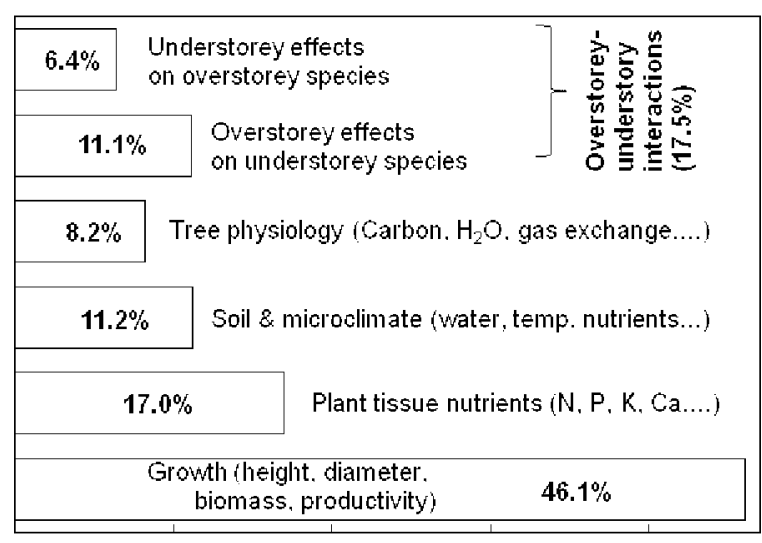

Distribution of published research papers $(\%)$

Figure 1. Distribution of published research papers dealing with plant-plant interaction in forest ecosystems (evaluation of 330 publications found in ISI Web of Science by the end of 2010, using combinations of key words of 1) 'forest*' or 'tree*' and 'competition' and 'facilitation', 2) 'forest*', 'weed control' and 'effect*', and 3) 'overstor*', 'understor*' and 'interaction*'). A research paper that dealt with 2 main subject categories was duplicately even triplicately recorded. This survey did not include research related to allelopathic phenomena, biodiversity and conservation, and mycorrhizal issues. Review papers, $\mathrm{PhD}$ and MSc theses were disregarded. Research related to overstorey-understorey interactions has not been further distinguished into other subject categories such as growth and physiology.

of the desired trees. On the other hand, the overstorey-understorey interactions, especially the possible effects of understorey plants on the growth and physiology of the overstorey trees, have received less attention. For example, research related to overstorey-understorey interactions had only a total fraction of $17.5 \%$ consisting of overstorey effects on understorey plants $(11.1 \%)$ and understorey effects on overstorey trees (6.4\%) (Fig. 1), and the majority of those $6.4 \%$ papers concentrated on weed control for juvenile trees in reforestation or agroforestry systems.

\section{Effects of neighboring woody plants on growth of desired trees}

Nearly $50 \%$ of the published works dealt with the growth effects of plant-plant interactions in forest ecosystems (Fig. 1), part of which focused on stand-level productivity in terms of total stand biomass, and the another part on individual-tree growth rate in terms of merchantable timber. Recently, many studies concentrated on the facilitative effects of nitrogenfixing trees/shrubs (e.g., Acacia spp., Alnus spp., Casuarina equisetifolia, Ceanothus spp., Leucaena leucocephala, Robinia pseudoacacia, etc.) on non-nitrogen-fixing target trees (Parrotta 1999, Bauhus et al. 2004, Nichols et al. 2006, Oakley et al. 2006). Many studies examined the growth performance of trees grown in mixtures with a nitrogen-fixing species compared to monoculture, i.e., the inter-specific vs. intra-specific effects on height growth (Groninger et al. 1997, Linden and Agestam 2003, Boyden et al. 2005), pro- 
ductivity (Binkley et al. 1992, Parrotta 1999, Bristow et al. 2006, Erskine et al. 2006, Forrester et al. 2006b), C-allocation (Shainsky et al. 1992, Kaye et al. 2000, Forrester et al. 2006a), and stand development (Groninger et al. 1996b, DeBell et al. 1997, Binkley et al. 2003, Kelty 2006). These investigations demonstrated that mixed plantations can achieve greater productivity than monocultures (DeBell et al. 1985, Binkley et al. 1992, DeBell et al. 1997, Parrotta 1999, Forrester et al. 2006b, Kelty 2006, Richards et al. 2010, Richards and Schmidt 2010), and such positive growth effects have been explained as results of enhanced soil nutrients availability and cycling caused by the presence of the nitrogen-fixing species (Carlyle and Malcolm 1986a, b, Parrotta 1999, Rothe and Binkley 2001).

It is widely accepted that $\mathrm{N}$ can be transferred from the $\mathrm{N}$-fixing species to the companion species (Kelty 2006). The $\mathrm{N}$ transfer mechanism is explained that the soil $\mathrm{N}$ availability increased since the soil $\mathrm{N}$ pool increased via decomposition of dead leaves and roots with high $\mathrm{N}$ contents of those $\mathrm{N}$-fixing plants. An increase in leaf/needle $\mathrm{N}$ contents led to increases in photosynthetic rate (Martindale and Leegood 1997, Davey et al. 1999, Kitajima and Hogan 2003, DiazEspejo et al. 2007), resulting in higher growth rate and productivity. On the other hand, a mixed stand may use the space and resources more effectively than a pure stand. For instance, in crop science it has been well-documented that the intercropping system greatly contributed to crop production by its effective utilization of resources, as compared to the monoculture cropping system (Cakmak et al. 2007).

Similarly, thinning has generally been recognized to reduce competition and to increase $\mathrm{N}$ availability and, further, enhance radial growth of remained trees (Youngberg 1975, Hocker 1982, Harrington and Reukema 1983, Simard et al. 2004). For example, individual stem diameter growth in Pinus taeda was found to be $51 \%$ higher in thinned stand compared to unthinned stands (Ginn et al. 1991). For Scots pine (Pinus sylvestris) at dry sites, quadratic mean diameter increments increased with thinning intensity and the response of diameter growth to thinning was greater in young trees (less than 50 years) and in medium sized trees compared to older ones (Makinen and Isomaki 2004). Both ponderosa pine (Pinus ponderosa) in southeastern USA and Norway spruce (Picea abies) in Belgium showed a long-term positive effect of decadal thinning on growth over up to 50 years (McDowell et al. 2003, Misson et al. 2003). Such positive and long-term lasting effects of thinning on the remained trees were mainly explained as results of reduced competition and increased resource availability (Youngberg 1975, Hocker 1982, Harrington and Reukema 1983, Simard et al. 2004). But the physiological mechanisms underlying those positive growth effects have been poorly understood so far (Makinen and Isomaki 2004).

\section{Overstorey effects on understorey woody plants}

About $11 \%$ of the published works dealt with overstorey effects on understorey vegetation such as nurse effects and overstorey competition (Fig. 1). Facilitation (e.g., nurse effect) and competition effects of overstorey on the germination and recruitment, and seedling establishment of other woody species under a canopy have been extensively reported (Oren et al. 1987, Fulbright et al. 1997, Takahashi 1997, Lloret et al. 2005, O'Brien et al. 2007, Munguia-Rosas and Sosa 2008). Canopy cover is one of the most important factors affecting understorey species diversity and composition in forest stands (Sagar et al. 2008). Overstorey removal led to changes in understorey composition and increase in species diversity (Ram et al. 2004, Elliott and Knoepp 2005). Understorey vegetation was found to change considerably and dynamically with overstorey structure and composition related to canopy cover (Hart and Chen 2006). After canopy closure, understorey composition shifted to the dominance of shade tolerant species with a decline in number, cover, and abundance of vascular plant species but an increase in bryophytes. Consequently, herbaceous production decreased in a linear or nonlinear manner as overstorey timber volume or canopy cover increased (Joyce and Baker 1987). Vascular plant cover was highest under deciduous stands and decreased with increasing conifer content (Legare et al. 2002), indicating that overstorey composition associated with canopy coverage significantly affects the understorey vegetation communities. These studies indicated that the effects of overstorey trees on the understorey vegetation seem to depend on (1) the sunlight reaching the forest floor and (2) on the shadetolerance of the understorey species (O'Brien et al. 2007, Parker and Dey 2008).

The presence of overstorey canopy can lead to significant reduction in the understorey growth and productivity (Hagan et al. 2009, Manceur et al. 2009, Perry et al. 2009). For example, Hagan et al. (2009) reported that Callicarpa americana, Morella cerifera, and Ilex glabra grown separately alone under a canopy (canopy coverage $\sim 35 \%$ ) of 15 -yearold longleaf pine (Pinus palustris) stand, had a biomass reduction of $-75.5,-50.6$, and $-68.7 \%$, respectively, compared to their monoculture (i.e., without an overstorey canopy).

Net photosynthesis and leaf conductance to water vapor of red oak (Quercus rubra) and sugar maple (Acer saccharum) seedlings significantly increased with decreased canopy density of overstorey (Parker and Dey 2008), indicating marked overstorey effects on understorey ecophysiology (Granhus and Braekke 2001). However, the presence of an overstorey canopy of Prosopis glandulosa var. glandulosa had no effects on the growth and physiology of the understorey shrubs of Zanthoxylum fagara and Berberis trifoliolata (Barnes and Archer 1999). Perry et al. (2009) found that the physiological responses of understorey to overstorey depended on the species of the overstorey trees (i.e., Pinus sylvestris vs. Fraxinus pennsylvancia in that study), or varied with understorey species itself (i.e., Andropogon gerardii, Bromus inermis, Lotus corniculatus). Similar results were also reported by Manceur et al. (2009). McKenzie et al. (2000) stated that the relationships between understorey development and overstorey conditions represented both direct resource limitations and time-dependent responses. Hence, 
we may conclude that the understorey responses to overstorey are results from overstorey-induced changes in understorey environment such as light availability, substrate, temperature, soil nutrients, and $\mathrm{pH}$.

\section{Effects of neighboring woody plants on tree nutrients}

Seventeen percent $(17.0 \%)$ of the published works related to plant-plant interactions in forest ecosystems investigated nutrients status in tissues of trees grown in mixtures compared to monoculture (Fig. 1). The published data documented either an increase (Carlyle and Malcolm 1986a, Brozek 1990), a decrease (Kozovits et al. 2005), or no change (Groninger et al. 1997, Thelin et al. 2002) in leaf nutrients concentrations in trees grown in pure stands compared to mixtures with other woody plants (Parrotta 1999, Specht and Turner 2006).

Specht and Turner (2006) found that foliar N concentrations of trees ( 12 species) varied significantly with the co-existing woody species in mixed forest plantations in New South Wales, Australia. Increased tissue N contents were typically found in trees grown in mixtures with $\mathrm{N}$-fixers compared to monoculture, showing a nursing effect of N-fixers on $\mathrm{N}$ content in the co-existing trees. For example, leaf $\mathrm{N}$ concentrations increased in Eucalyptus globulus grown with Acacia mearnsii in plantations (Bauhus et al. 2004, Forrester et al. 2005) and in E. delegatensis grown with Acacia dealbata in a natural forest (Kuppers 1996). Binkley et al. (1984) and Brozek (1990) showed that Douglas-fir (Pseudotsuga menziesii) grown in mixtures with alder (Alnus sp.) had higher foliar $\mathrm{N}$ concentrations than those grown in the absence of alder. Foliar $\mathrm{N}$ concentrations of $P$. menziesii increased from $9.3 \mathrm{mg} \mathrm{g}^{-1}$ in monoculture to $14.1 \mathrm{mg} \mathrm{g}^{-1}$ in mixture with Alnus rubra (Binkley 1983).

On the other hand, Groninger et al. (1997) found that pine (Pinus taeda) foliar $\mathrm{N}$ did not vary with stand types (monoculture vs. mixture with Robinia pseudoacacia). Thelin et al. (2002) reported that there was no difference in $\mathrm{N}$ concentration in current-year needles of Picea abies grown in pure stand and mixtures with either beech, birch, or oak, respectively. Kozovits et al. (2005) found that beech grown in mixture with spruce had a significantly lower tissue $\mathrm{N}$ content, but spruce trees showed significant enhancement in its tissue $\mathrm{N}$ content in the mixed culture, compared to monoculture.

Similarly to those contradictory findings mentioned above, thinning effects on nutrients of remained trees have also been found to be positive, negative, or no effects. Hokka et al. (1996) reported that thinning increased foliar concentrations of $\mathrm{N}, \mathrm{P}$, and $\mathrm{K}$ in Pinus sylvestris trees, and concluded that thinning improved the foliar nutrient status by reducing the competition for nutrients. Velazquezmartinez et al. (1992) found that thinning improved $\mathrm{N}, \mathrm{K}$, and $\mathrm{Mg}$ concentrations in young trees of Douglas-fir (see also Medhurst and Beadle 2005). On the other hand, Jonard et al. (2006) found that N, P, and $\mathrm{K}$ concentrations in current-year needles of Picea abies trees were decreased by thinning $(\mathrm{p} \leq 0.05)$, while $\mathrm{Ca}, \mathrm{Mg}$, and $\mathrm{Na}$ concentrations were not affected. They concluded that thinning negatively affected $\mathrm{N}, \mathrm{P}$, and $\mathrm{K} \mathrm{nu-}$ trition by removing the nutrients contained in the thinned trees (Jonard et al. 2006).

A recent review paper also revealed that tissue nutrients $(\mathrm{N}, \mathrm{P})$ level in trees grown in mixture compared to monoculture varied from case to case (Richards et al. 2010). Hence, we may conclude that the nutrient levels in target trees reflect trees' ability of resource acquisition and resource-use efficiency which depend on the physiology and morphology of the target species itself and the interactions of the species assemblage within a community (see Nambiar and Sands, 1993, Binkley et al. 2004).

\section{Effects of neighboring woody plants on photosynthesis and water use efficiency in overstorey trees}

Only $8.2 \%$ of the published works related to plant-plant interactions in forest ecosystems investigated biochemical and physiological aspects of carbon metabolism in trees grown in mixtures compared to monoculture (Fig. 1). Richards et al. (2010) pointed out that "there are few examples where rates of photosynthesis have been compared for a given species in monoculture and mixture" (pp. 1200).

The mean light-saturated net photosynthesis rates of $E$. globulus were found to be significantly higher in monoculture $\left(14.6 \mu \mathrm{mol} \mathrm{CO} \mathrm{m}^{-2} \mathrm{~s}^{-1}\right.$ on a leaf area basis, or 0.053 $\mu \mathrm{mol} \mathrm{CO} \mathrm{g}^{-1} \mathrm{~s}^{-1}$ on a foliage mass basis) than in 1:1 mixture with A. mearnsii $\left(11.2 \mu \mathrm{mol} \mathrm{CO}_{2} \mathrm{~m}^{-2} \mathrm{~s}^{-1}\right.$, or $0.040 \mu \mathrm{mol}$ $\mathrm{CO}_{2} \mathrm{~g}^{-1} \mathrm{~s}^{-1}$ ) (Bauhus et al. 2004). In a greenhouse experiment with Loblolly pine (Pinus taeda) and Red maple (Acer rubrum) seedlings, Groninger et al. (1996b) reported that pure pine had lower photosynthesis rate than mixed pine under either ambient $\mathrm{CO}_{2}$ or elevated $\mathrm{CO}_{2}$ (c. 798 ppm) conditions, whereas pure maple had higher gas exchange rate under ambient $\mathrm{CO}_{2}$ but lower rate under elevated $\mathrm{CO}_{2}$ compared to mixed maple. Kozovits et al. (2005) found that the sun leaves of beech had similar net $\mathrm{CO}_{2}$ uptake rate in mono- and mixed cultures with spruce. But under elevated $\mathrm{CO}_{2}$ (c. 670 ppm), the net $\mathrm{CO}_{2}$ uptake rates of beech in mixed culture tended to be lower compared to those in monoculture (Kozovits et al. 2005).

Binkley et al. (2004) found that the light-saturated rate of photosynthesis in Eucalyptus saligna increased linearly with increasing $\mathrm{N}$ concentrations in leaves (see also Kume et al. 2003). Experimental studies also revealed that leaf photosynthetic rates of various plants/trees are positively correlated with leaf N content (Martindale and Leegood 1997, Davey et al. 1999, Kitajima and Hogan 2003, Diaz-Espejo et al. 2007). If an individual has competitive advantage over others for $\mathrm{N}$, water, and other resource, it must be able to (1) acquire a greater proportion of the soil resource, (2) use resource more efficiently for producing biomass, and (3) allocate assimilate in ways that will maximize capacity for growth (Nambiar and Sands 1993). 
Hence, it is possible that multispecies mixtures had higher water-use efficiency compared to monocultures, because different plant species can use soil water from different depths of the soil profile due to having contrasting water uptake strategies (Vandermeer 1989, Jose et al. 2006). Forrester et al. (2010) found that for every $\mathrm{m}^{3}$ of water transpired by Eucalyptus trees in mixtures produced more wood and aboveground biomass than those in monocultures in Australia. Again, Forrester et al. (2010) found that annual transpiration was 419,358 and $217 \mathrm{~mm}$ in the $1: 1$ mixture of $E$. globulus and A. mearnsii and in monoculture of E. globulus and $A$. mearnsii, respectively. However, at individual tree level, we found that very little is known about water-use efficiency of trees in mixtures compared to monocultures (see also Richards et al. 2010).

Several studies have investigated the short-term effects of thinning on physiology of remained trees. A decrease in stem density was associated with an increase in photosynthesis rate in Pseutotsuga menziesii and in Pinus ponderosa (Sala et al. 2005). An increase in photosynthesis rate could be partially associated with a decrease in light competition, in particular at the lower crown level (Ginn et al. 1991, Groninger et al. 1996a). In old ponderosa pine stands, thinned stands showed increases in stomatal conductance and carbon isotope discrimination in the wood up to 15 years following the treatment (Groninger et al. 1996c, Jonard et al. 2006). An increase in carbon isotopes discrimination reflected a decrease in water use-efficiency likely due to an increase in soil water availability in thinned stands (Bréda et al. 1995).

\section{Effects of understorey shrubs on overstorey carbon- and water physiology}

Only $6.4 \%$ of the published works dealt with understorey effects on overstorey trees in forest ecosystems (Fig. 1). Plants that occupy the overstorey layer have a clear advantage in the competition for light. When the overstorey plants develop a dense canopy and shade the understorey plants completely, overstorey plants will be successful in suppressing understorey plants by means of a monopoly of light resources. But a large water supply is also needed to keep dense canopy of overstorey. Spatial and temporal segregation of roots and shoots by neighbouring plants may be an effective strategy for reducing competition for space and resource (Balandier et al. 2006). For instance, shallow-rooted herbaceous species utilize water and other resource in top-soil and deep-rooted woody plants acquire separate resource from deeper soil horizons (Nambiar and Sands 1993, Casper and Jackson 1997, Balandier et al. 2006). However, even with a vertical stratification of root systems, the overstorey trees that have roots in the deep soil layer can also suffer from water deficit caused by dense understorey vegetation colonizing the upper horizon leading to an almost complete withdrawal of soil water in the upper soil layer and to a gradual drying of the deeper soil layers (Balandier et al. 2006). Hence, the understorey may be most likely to affect the overstorey through below-ground competition for soil resources
(Montgomery et al. 2010). For instance, many weed control/removal experiments carried out in tree plantations and agroforestry systems showed that dense understorey weeds led to increased water stress in crop trees (Carter et al. 1984, Elliott and White 1987, Petersen et al. 1988, Nambiar and Sands 1993). Needle water potential of juvenile Pinus radiata plants decreased when weeds were present (Sands and Nambiar 1984, Watt et al. 2003), and a negative linear relationship between percentage cover of weeds and $P$. radiata needle water potential has also been reported (Nambiar and Zed 1980).

Miller et al. (1998) carried out an experiment in low rainfall area in New Zealand, and reported that trees (Pinus radiata, $\sim 3.4 \mathrm{~m}$ in height) grown with an understorey of cocksfoot (Dactylis glomerata) had lower xylem sap flux and total canopy conductance than trees grown with an understorey of ryegrass (Lolium perenne), indicating that different understorey species imposed different degrees of competition for water on the overstorey trees. Both competition for natural resources between the overstorey trees and the understorey vegetation, and the effects of understorey vegetation on modifying the micro-environmental conditions, may affect the physiology of the overstorey trees, leading to changes in growth rate (see also Fig. 3). For example, Watt et al. (2003) reported that, after 2-years of weed treatment, young $P$. radiata tress grown in the absence of weeds had an aboveground biomass 25 -fold greater than that of trees grown in the presence of weeds. To understand the effects of understorey shrubs on overstorey trees, Kume et al. (2003) reported that Pinus densiflora trees grown in the presence of understorey shrubs (Eurya japonica, Ilex pedunculosa, Symplocos lucida, Rhododendron reticulatum) had smaller maximum net photosynthesis and stomatal conductance but greater needle $\delta{ }^{13} \mathrm{C}$ values compared to trees grown in the absence of the understorey shrubs (removed). They also found that needle nitrogen contents and photosynthetic nitrogen use efficiency in trees grown in the presence of understorey shrubs were lower than in the absence of understorey vegetation (Kume et al. 2003, see also Binkley et al. 2004). Similar photosynthetic responses of Pinus banksiana trees to grasses (Poa pratensis, Festuca spp.) (Mohammed et al. 1998) and E. globulus trees to A. mearnsii (Bauhus et al. 2004) have been reported. Their results consistently indicated that understorey vegetation negatively affected the physiological activities in overstorey trees, although the understorey species varied among the 3 case studies from grasses (Mohammed et al. 1998) to shrubs (Kume et al. 2003, Bauhus et al. 2004).

Photosynthesis is only one aspect, but what is more important is the carbon balance between carbon gain (photosynthesis) and loss (respiration) within a tree (Körner 2003, Li et al. 2008b). This balance (= carbon gain - carbon loss) is commonly described using the concentration or pool size of mobile carbohydrates (Li et al. 2001, Hoch et al. 2002, Li et al. 2002, Hoch et al. 2003, Körner 2003, Li et al. 2008a, Li et al. 2008b), since mobile carbohydrates represent a tree's capital for growth (Hoch et al. 2002, Li et al. 2002, Körner 
2003). Shainsky and Rose (1995) reported that concentrations of starch and TNC (total non-structural carbohydrates) in needles of Douglas-fir (P. menziesii) trees decreased significantly in mixture with alder (Alnus rubra), but needle sugars did not differ between trees grown in monoculture and mixture.

Li et al. (Li, Pan, Du et al., unpublished data) found that levels of N, non-structural carbohydrate (NSC) and its components (soluble sugars, starch) in overstorey Abies faxoniana trees varied significantly with the co-existing mid-storey shrubs (Table 1), indicating that (1) co-existing understorey shrubs altered the $\mathrm{N}$ and $\mathrm{C}$ metabolism in the overstorey trees, and (2) different understorey species with different physioecological properties affected the overstorey physiology differently. To test those findings (Table 1) gained using natural experiments, Du et al. (unpublished) studied the status of N and NSC in China fir (Cunninghamia lanceolata) trees grown in the presence and absence of mid-storey shrubs using mid-storey removal experiments. Their results indicated that the presence of mid-storey shrubs resulted in lower levels of mobile carbohydrates in tissues of overstorey trees compared to the absence of mid-storey plants (Table 2, Fig. 2). These studies highlighted the roles of understorey vegetation in determining the carbon and nitrogen physiology of overstorey trees (Tables 1 and 2, Fig. 2). Moreover, Du et al. also found that the understorey effects on N and NSC in overstorey trees differed between the dry season and rainy season (Fig. 2). This may imply that the understorey effects on overstorey trees may be mainly resulted from understorey competition for soil water rather than for other resources in the study area. Hence, positive or negative physiological effects of understorey management on overstorey trees may be dependent on understorey-specific properties (e.g., N-fixers or non N-fixers) (Table 1; see also Forrester et al. 2007 vs. Kume et al. 2003), timing and duration of understorey man- agement (Adams et al. 2003, Balandier et al. 2006), and also on site conditions (e.g., dry site vs. wet site; Fig. 2).

\section{Effects of understorey shrubs on soil temperature and soil water contents}

The understorey effects on overstorey trees, as described above, seemed to result from belowground competition rather than from aboveground interaction. About $11 \%$ of the published papers studied the understorey effects on soil temperature, water contents, nutrients, microorganisms, etc. (Fig. 1). It is well-documented that dense understorey vegetation can significantly decrease the soil temperature, net $\mathrm{N}$ mineralization, net nitrification rates, and soil water availability (Matsushima and Chang 2006, 2007, Devine and Harrington 2008, Wang et al. 2011, Yildiz et al. 2011, Zhao et al. 2011). Understorey removal can lead to significant increase in soil N (Tripathi et al. 2005, Matsushima and Chang 2006, Tripathi et al. 2006, Matsushima and Chang 2007) and soil water availability (Takahashi et al. 2003, Matsushima and Chang 2007), and consequently, resulting in increased growth rate of the overstorey trees (Oren et al. 1987, Takahashi et al. 2003). For example, we removed the understorey shrubs $(\sim 55 \%$ coverage $)$ in three forest plantations (Cryptomeria japonica, Taiwania flousiana, Metasequoia glyptostroboides) in southwestern China in April 2008, and measured the soil temperature and soil water contents during the growing season from May to October 2008. Our data (Du et al., unpublished) indicated that the mean growing season soil temperature $(-10 \mathrm{~cm})$ and soil water contents were 0.64 $1.24{ }^{\circ} \mathrm{C}$ and $8.3-9.9 \%$ higher in understorey-removed sites than in forest plantations with intact understorey, respectively. Increased soil temperature did not result in decreased soil water contents, indicating that the understorey-transpirational water loss exceeded the faster evaporation caused by

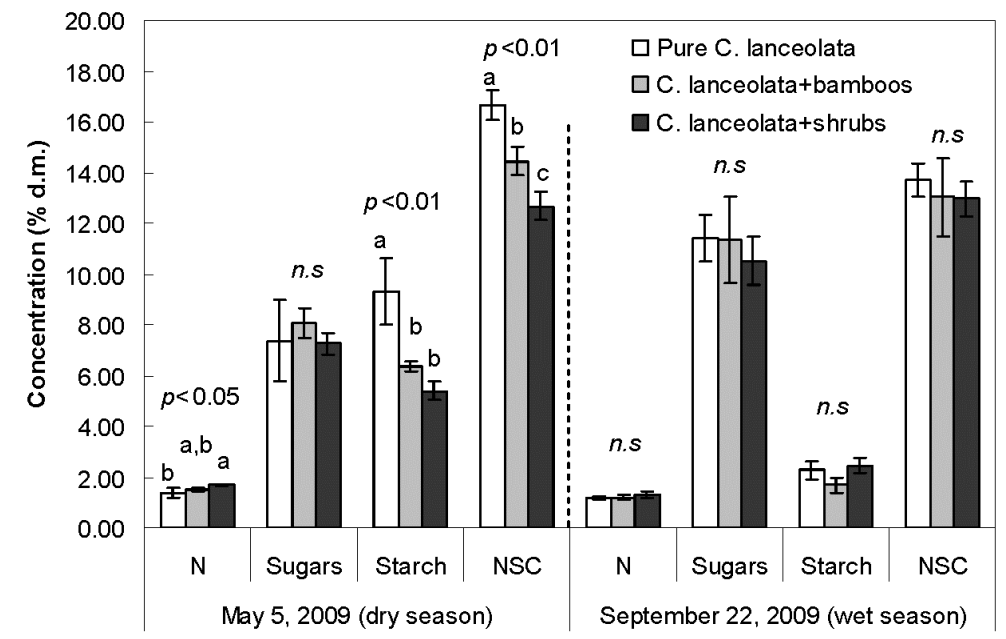

Figure 2. Concentration (\% d.m. $\pm 1 \mathrm{SD}, n=3$ ) of total nitrogen, non-structural carbohydrate (NSC) and its components (soluble sugars, starch) in previous-year needles ( $\geq 1$-yr-old) of Cunninghamia lanceolata trees grown in the absence (pure C. lanceolata) and presence of mid-stories at $1600 \pm 100 \mathrm{~m}$ a.s.l. on a gentle SE-facing slope, Chongzhou, SW China (Du, $\mathrm{Li}$, Pan, unpublished data). Needle samples were taken during the dry (May 5-7) and rainy season (September 22-26) in 2009. Statistical differences were tested using one-way ANOVAs, and followed, if significant, by Tukey's HSD test. Different letters indicate significant differences at $p<.05$. n.s., $p>0.05$. See note for Table 2. 


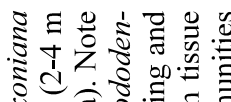

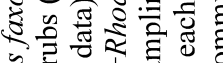

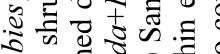

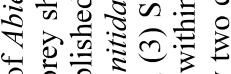

品

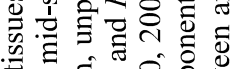

a

승.

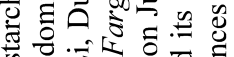

运记

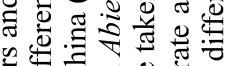

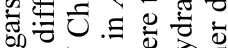

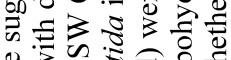

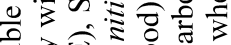

응

तो

至

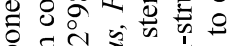

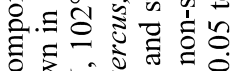

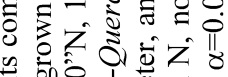

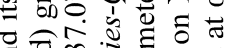

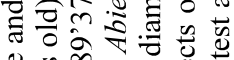

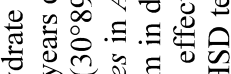

날

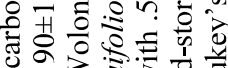

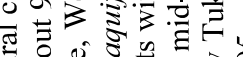

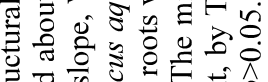

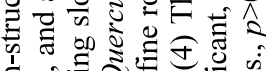

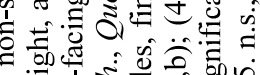

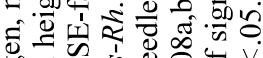

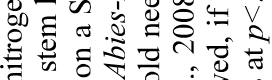

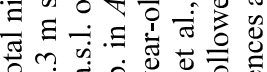

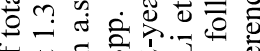

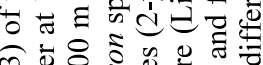

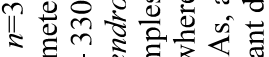
कि:

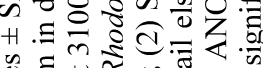

造 के के

किष

है

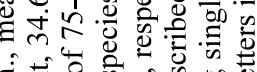

हो

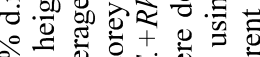

过

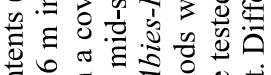

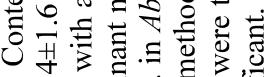

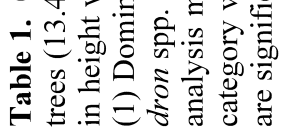

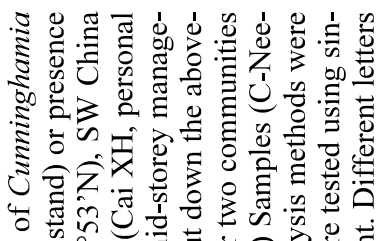

H

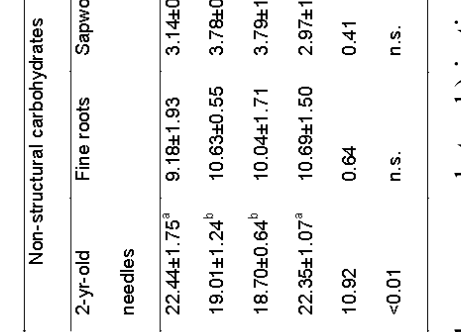

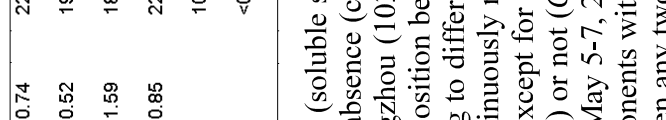

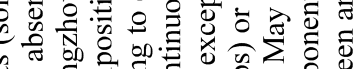

等

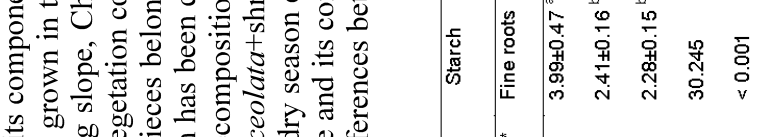

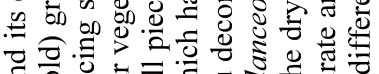

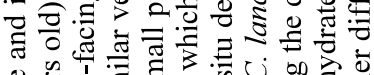

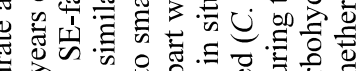

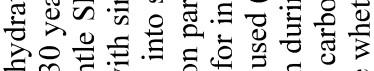
然 100 数穴

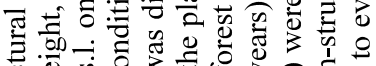

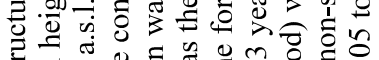

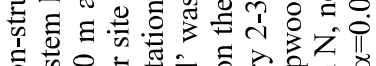

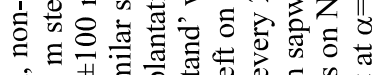

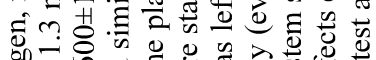
等

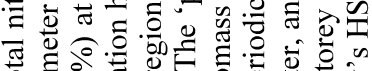

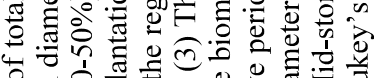

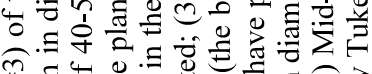

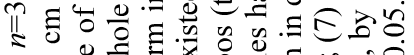

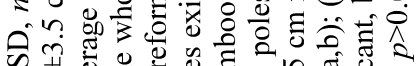
की मे

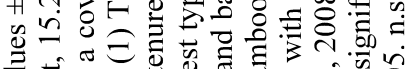

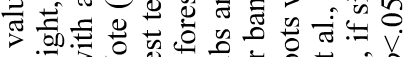

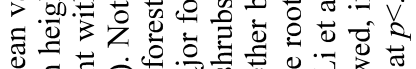

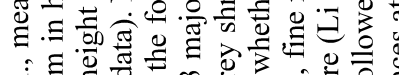
हं

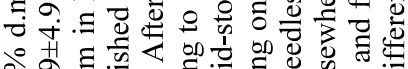
OQ.

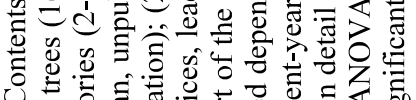

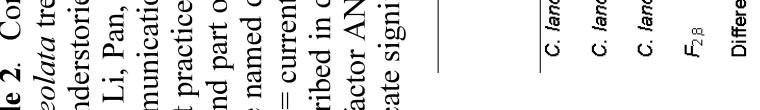

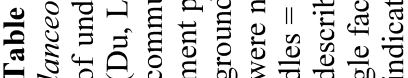

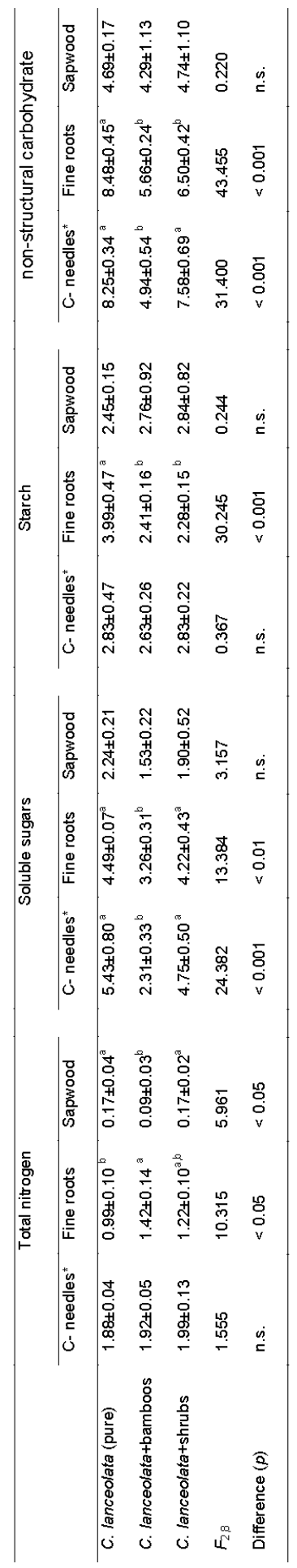


higher temperature on the forest floor. Hence, effects of understorey shrubs on ecophysiology of overstorey trees were found to be more pronounced during the dry season than in the wet season (Fig. 2).

\section{Management implications and suggestions for further research}

Co-existing trees/herbs require water, $\mathrm{CO}_{2}$, light, nitrogen, phosphorus, potassium and a common set of minor mineral nutrients. Different species acquire these resources in similar ways, and interspecific competition for these resources is the norm in plant communities (Barot 2004, Silvertown 2004). Plant-plant interaction can be classified as either competitive or facilitative, and divided mainly into aboveground and belowground categories (Montgomery et al. 2010). Negative and positive interactions of plants within a community have been intensely studied (Nambiar and Sands 1993, Bertness and Callaway 1994, Callaway and Walker 1997, Brooker and Callaghan 1998, Montgomery et al. 2010), as mentioned in previous paragraphs. However, it is still poorly understood how the individual physiology responds to and reflects the balance between positive and negative interactions, and how those will change with rapid environmental changes (Fig. 3). For instance, Zhang et al. (2008, 2009a) experimentally revealed that plant-plant interactions such as intensity and importance of competition were altered by environmental changes.

For hundreds of years understorey removal and thinning have been used as effective forest management practices to improve the commercial timber worldwide. It is well-documented that thinning and understorey removal can not only reduce the competition but also improve the soil quality including soil temperature, water and nutrients availability, and further, enhance the growth rate (Roberts and Harrington

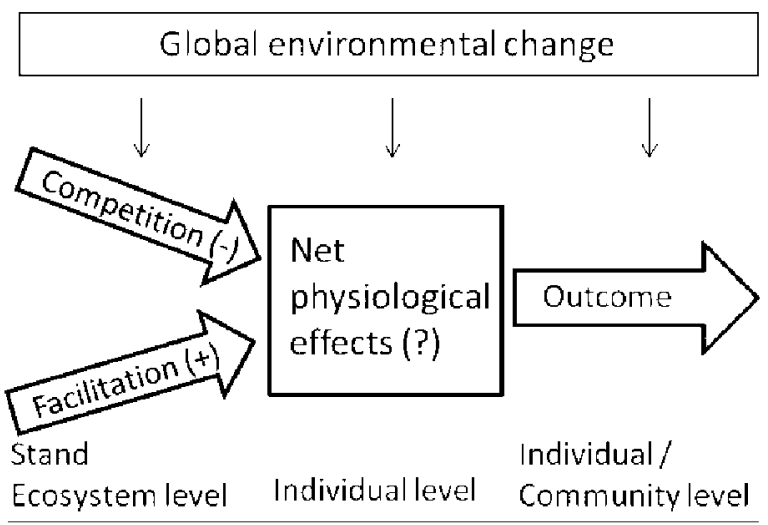

Figure 3. A diagram showing facilitative and competitive interactions and their effects on outcome at individual and community level. Negative and positive interactions and their effects on growth have been intensely studied, but it is poorly understood how net physiological responses of plants reflect the balance between mutualistic and competitive interactions, and how all those will be altered by a rapidly changing world.
2008, Weiskittel et al. 2009, Zhang et al. 2009b, Tian et al. 2010). But, we still do not understand the physiological mechanism underlying those positive growth effects of thinning and understorey removal (Fig. 3). We also still do not know whether an enhanced growth rate of desired trees is caused by or correlated with increases in physiological activities (e.g., photosynthesis, water use efficiency, availability of nutrients and mobile carbohydrates, a balanced carbon gain and loss, etc.) of desired trees due to enhanced resource availability after management practice.

The present paper suggests that positive effects of thinning and understorey cut on target trees can be expected more rapidly and strongly in stressful area (e.g., low rainfall, nutrient-poor site) rather than in areas with optimal growth conditions, based on results shown in Figure 2. In that experiment (Fig. 2), the understorey biomass cut down was left on the forest floor to decompose in situ. The thinned biomass and the understorey biomass cut down in previous experiments, however, were normally removed from the forests studied. This means that the remained trees suffer directly from a net loss of nutrients contained in that biomass. Hence, it is needed to distinguish the effects of reduced nutrients storage from effects of reduced competition on remained trees. But anyway, through the present literature review we could conclude that the co-existing woody plants can affect the $\mathrm{C}$ - and N-physiology (Tables 1 and 2, Fig. 2), growth, and productivity in desired trees.

The present paper can help us to better understand the physiological mechanism for neighbor-dependent growth performance of trees, and to develop ecophysiology-based management strategies for dealing with neighboring plants in forest ecosystems. However, the world is facing the challenge of global warming and biodiversity loss. Hence, on the other hand, (1) the question of whether neighbor removal can also lead to fixing more $\mathrm{CO}_{2}$ per unit area still awaits a conclusive answer; and (2) possible negative effects of neighbor removal on biodiversity conservation and soil erosion should also be taken into account.

Acknowledgements: The authors thank the two anonymous reviewers for valuable comments/suggestions on the manuscript. This work was supported by the National Natural Science Foundation of China (Project No. 40771071) and by the Key Laboratory of Forest Ecology and Environment, State Forestry Administration, Chinese Academy of Forestry (Project No. CAFIFEEPYBB2007001).

\section{References}

Adams, P.R., C.L. Beadle, N.J. Mendham and P.J. Smethurst. 2003. The impact of timing and duration of grass control on growth of a young Eucalyptus globulus Labill. plantation. New Forests 26: 147-165.

Aerts, R. 1999. Interspecific competition in natural plant communities: mechanisms, trade-offs and plant-soil feedbacks. J. Exp. Bot. 50: 29-37.

Aphalo, P.J., C.L. Ballare and A.L. Scopel. 1999. Plant-plant signalling, the shade-avoidance response and competition. J. Exp. Bot. 50: 1629-1634 
Balandier, P., C. Collet, J.H. Miller, P.E. Reynolds and S.M. Zedaker. 2006. Designing forest vegetation management strategies based on the mechanisms and dynamics of crop tree competition by neighbouring vegetation. Forestry 79: 3-27.

Barnes, P.W. and S. Archer. 1999. Tree-shrub interactions in a subtropical savanna parkland: Competition or facilitation? J. Veg. Sci. 10: 525-536.

Barot, S. 2004. Mechanisms promoting plant coexistence: can all the proposed processes be reconciled? Oikos 106: 185-192.

Bauhus, J., A.P. van Winden and A.B. Nicotra. 2004. Aboveground interactions and productivity in mixed-species plantations of Acacia mearnsii and Eucalyptus globulus. Can. J. Forest Res. 34: 686-694.

Bertness, M.D. and R. Callaway. 1994. Positive interactions in communities. Trends Ecol. Evol. 9: 191-193.

Binkley, D. 1983. Ecosystem production in Douglas-fir plantations Interaction of red alder and site fertility. Forest Ecol. Manage. 5: 215-227.

Binkley, D., K.A. Dunkin, D. DeBell and M.G. Ryan. 1992. Production and nutrient cycling in mixed plantations of Eucalyptus and Albizia in Hawaii. Forest Sci. 38: 393-408.

Binkley, D., J.D. Lousier and K. Cromack. 1984. Ecosystem effects of Sitka alder in a Douglas-fir plantation. Forest Sci. 30: 26-35.

Binkley, D., R. Senock, S. Bird and T.G. Cole. 2003. Twenty years of stand development in pure and mixed stands of Eucalyptus saligna and nitrogen-fixing Facaltaria moluccana. Forest Ecol. Manage. 182: 93-102.

Binkley, D., J.L. Stape and M.G. Ryan. 2004. Thinking about efficiency of resource use in forests. Forest Ecol. Manage. 193: 516.

Boyden, S., D. Binkley and R. Senock. 2005. Competition and facilitation between Eucalyptus and nitrogen-fixing Falcataria in relation to soil fertility. Ecology 86: 992-1001.

Bréda, N., A. Granier and G. Aussenac. 1995. Effects of thinning on soil and tree water relations, transpiration and growth in an oak forest (Quercus petraea (Matt) Liebl). Tree Physiol. 15: 295306.

Bristow, M., J.K. Vanclay, L. Brooks and M. Hunt. 2006. Growth and species interactions of Eucalyptus pellita in a mixed and monoculture plantation in the humid tropics of north Queensland. Forest Ecol. Manage. 233: 285-294.

Brooker, R.W. 2006. Plant-plant interactions and environmental change. New Phytol. 171: 271-284.

Brooker, R.W. and T.V. Callaghan. 1998. The balance between positive and negative plant interactions and its relationship to environmental gradients: a model. Oikos 81: 196-207.

Brooker, R.W., F.T. Maestre, R.M. Callaway, C.L. Lortie, L.A. Cavieres, G. Kunstler, P. Liancourt, K. Tielborger, J.M.J. Travis, F. Anthelme, C. Armas, L. Coll, E. Corcket, S. Delzon, E. Forey, Z. Kikvidze, J. Olofsson, F. Pugnaire, C.L. Quiroz, P. Saccone, K. Schiffers, M. Seifan, B. Touzard and R. Michalet. 2008. Facilitation in plant communities: the past, the present, and the future. J. Ecol. 96: 18-34.

Brozek, S. 1990. Effect of soil changes caused by red alder (Alnus rubra) on biomass and nutrient status of Douglas fir (Pseudotsuga menziesii) seedlings. Can. J. Forest Res. 20: 1320-1325.

Cakmak, I., A. Inal, A. Gunes and F. Zhang. 2007. Peanut/maize intercropping induced changes in rhizosphere and nutrient concentrations in shoots. Plant Physiol. Bioch. 45: 350-356.
Callaway, R.M. and L.R. Walker. 1997. Competition and facilitation: A synthetic approach to interactions in plant communities. Ecology 78: 1958-1965.

Carlyle, J.C. and D.C. Malcolm. 1986a. Nitrogen availability beneath pure spruce and mixed larch + spruce stands growing on a deep peat. 1 . Net $\mathrm{N}$ mineralization measured by field and laboratory incubations. Plant and Soil 93: 95-113.

Carlyle, J.C. and D.C. Malcolm. 1986b. Nitrogen availability beneath pure spruce and mixed larch + spruce stands growing on a deep peat. 2. A comparison of $\mathrm{N}$ availability as measured by plant uptake and long-term laboratory incubations. Plant and Soil 93: 115-122.

Carter, G.A., J.H. Miller, D.E. Davis and R.M. Patterson. 1984. Effect of vegetative competition on the moisture and nutrient status of loblolly-pine. Can. J. Forest Res. 14: 1-9.

Casper, B.B. and R.B. Jackson. 1997. Plant competition underground. Annu. Rev. Ecol. Syst. 28: 545-570.

Curran, L.M., I. Caniago, G.D. Paoli, D. Astianti, M. Kusneti, M. Leighton, C.E. Nirarita and H. Haeruman. 1999. Impact of El Nino and logging on canopy tree recruitment in Borneo. Science 286: 2184-2188.

Davey, P.A., A.J. Parsons, L. Atkinson, K. Wadge and S.P. Long. 1999. Does photosynthetic acclimation to elevated $\mathrm{CO}_{2}$ increase photosynthetic nitrogen-use efficiency? A study of three native UK grassland species in open-top chambers. Funct. Ecol. 13: 21-28.

DeBell, D.S., T.G. Cole and C.D. Whitesell. 1997. Growth, development, and yield in pure and mixed stands of Eucalyptus and $\mathrm{Al}$ bizia. Forest Sci. 43: 286-298.

DeBell, D.S., C.D. Whitesell and T.H. Schubert. 1985. Mixed plantations of Eucalyptus and Leguminous trees enhance biomass production. USDA Forest Service Pacific Southwest Research Station Research Paper: 1-6.

Devine, W.D. and T.B. Harrington. 2008. Belowground competition influences growth of natural regeneration in thinned Douglas-fir stands. Can. J. Forest Res. 38: 3085-3097.

Diaz-Espejo, A., E. Nicolas and J.E. Fernandez. 2007. Seasonal evolution of diffusional limitations and photosynthetic capacity in olive under drought. Plant Cell Environ. 30: 922-933.

Dudareva, N., F. Negre, D.A. Nagegowda and I. Orlova. 2006. Plant volatiles: Recent advances and future perspectives. Critical Rev. Plant Sci. 25: 417-440.

Elliott, K.J. and J.D. Knoepp. 2005. The effects of three regeneration harvest methods on plant diversity and soil characteristics in the southern Appalachians. Forest Ecol. Manage. 211: 296-317.

Elliott, K.J. and A.S. White. 1987. Competitive effects of various grasses and forbs on Ponderosa pine-seedlings. Forest Sci. 33: 356-366.

Erskine, P.D., D. Lamb and M. Bristow. 2006. Tree species diversity and ecosystem function: Can tropical multi-species plantations generate greater productivity? Forest Ecol. Manage. 233: 205210 .

Forrester, D.I., J. Bauhus and A.L. Cowie. 2005. Nutrient cycling in a mixed-species plantation of Eucalyptus globulus and Acacia mearnsii. Can. J. Forest Res. 35: 2942-2950.

Forrester, D.I., J. Bauhus and A.L. Cowie. 2006a. Carbon allocation in a mixed-species plantation of Eucalyptus globulus and Acacia mearnsii. Forest Ecol. Manage. 233: 275-284.

Forrester, D.I., J. Bauhus, A.L. Cowie and J.K. Vanclay. 2006 b. Mixed-species plantations of Eucalyptus with nitrogen-fixing trees: A review. Forest Ecol. Manage. 233: 211-230. 
Forrester, D.I., J. Bauhus, A.L. Cowie, P.A. Mitchell and J. Brockwell. 2007. Productivity of three young mixed-species plantations containing $\mathrm{N}_{2}$-fixing Acacia and non- $\mathrm{N}_{2}$-fixing Eucalyptus and Pinus trees in southeastern Australia. Forest Sci. 53: 426-434.

Forrester, D.I., S. Theiveyanathan, J.J. Collopy and N.E. Marcar. 2010. Enhanced water use efficiency in a mixed Eucalyptus globulus and Acacia mearnsii plantation. Forest Ecol. Manage. 259: 1761-1770.

Fulbright, T.E., J.O. Kuti and A.R. Tipton. 1997. Effects of nurseplant canopy light intensity on shrub seedling growth. J. Range Manage. 50: 607-610.

Gause, G.F. 1934. The Struggle for Existence. Williams and Wilkins, Baltimore.

Ginn, S.E., J.R. Seiler, B.H. Cazell and R.E. Kreh. 1991. Physiological and growth-responses of 8-year-old Loblolly-pine stands to thinning. Forest Sci. 37: 1030-1040.

Grace, J.B. and D. Tilman. 1990. Perspectives on Plant Competition. Academic Press, New York.

Grams, T.E.E., A.R. Kozovits, I.M. Reiter, J.B. Winkler, M. Sommerkorn, H. Blaschke, K.H. Haberle and R. Matyssek. 2002. Quantifying competitiveness in woody plants. Plant Biol. 4: 153-158.

Granhus, A. and F.H. Braekke. 2001. Nutrient status of Norway spruce stands subjected to different levels of overstorey removal. Trees-Structure and Function 15: 393-402.

Groninger, J.W., J.R. Seiler, J.A. Peterson and R.E. Kreh. 1996a. Growth and photosynthetic responses of four Virginia Piedmont tree species to shade. Tree Physiol. 16: 773-778.

Groninger, J.W., J.R. Seiler, S.M. Zedaker and P.C. Berrang. 1996b. Effects of $\mathrm{CO}_{2}$ concentration and water availability on growth and gas exchange in greenhouse-grown miniature stands of Loblolly Pine and Red Maple. Funct. Ecol. 10: 708-716.

Groninger, J.W., J.R. Seiler, S.M. Zedaker and P.C. Berrang. 1996c. Photosynthetic response of loblolly pine and sweetgum seedling stands to elevated carbon dioxide, water stress, and nitrogen level. Can. J. Forest Res. 26: 95-102.

Groninger, J.W., S.M. Zedaker and T.S. Fredericksen. 1997. Stand characteristics of inter-cropped loblolly pine and black locust. Forest Ecol. Manage. 91: 221-227.

Hagan, D.L., S. Jose, M. Thetford and K. Bohn. 2009. Production physiology of three native shrubs intercropped in a young longleaf pine plantation. Agroforestry Systems 76: 283-294.

Harrington, C.A. and D.L. Reukema. 1983. Initial shock and longterm stand development following thinning in a Douglas-fir plantation. Forest Sci. 29: 33-46.

Hart, S.A. and H.Y.H. Chen. 2006. Understory vegetation dynamics of North American boreal forests. Critical Rev. Plant Sci. 25: 381-397.

Hoch, G., M. Popp and C. Körner. 2002. Altitudinal increase of mobile carbon pools in Pinus cembra suggests sink limitation of growth at the Swiss treeline. Oikos 98: 361-374.

Hoch, G., A. Richter and C. Körner. 2003. Non-structural carbon compounds in temperate forest trees. Plant Cell Environ. 26: 1067-1081.

Hocker, H.W. 1982. Effects of thinning on biomass growth in young Populus tremuloides plots. Can. J. Forest Res. 12: 731-737.

Hokka, H., T. Penttila and B. Hanell. 1996. Effect of thinning on the foliar nutrient status of Scots pine stands on drained boreal peatlands. Can. J. Forest Res. 26: 1577-1584.
Jonard, M., L. Misson and Q. Ponette. 2006. Long-term thinning effects on the forest floor and the foliar nutrient status of Norway spruce stands in the Belgian Ardennes. Can. J. Forest Res. 36: 2684-2695.

Jose, S., R. Williams and D. Zamora. 2006. Belowground ecological interactions in mixed-species forest plantations. Forest Ecol. Manage. 233: 231-239.

Joyce, L.A. and R.L. Baker. 1987. Forest overstory understory relationships in Alabama forests. Forest Ecol. Manage. 18: 49-59.

Kaye, J.P., S.C. Resh, M.W. Kaye and R.A. Chimner. 2000. Nutrient and carbon dynamics in a replacement series of Eucalyptus and Albizia trees. Ecology 81: 3267-3273.

Keddy, P.A. 1989. Competition. Chapman and Hall, New York.

Kelty, M.J. 2006. The role of species mixtures in plantation forestry. Forest Ecol. Manage. 233: 195-204.

Kitajima, K. and K.P. Hogan. 2003. Increases of chlorophyll a/b ratios during acclimation of tropical woody seedlings to nitrogen limitation and high light. Plant Cell Environ. 26: 857-865.

Körner, C. 2003. Carbon limitation in trees. J. Ecol. 91: 4-17.

Kozovits, A.R., R. Matyssek, H. Blaschke, A. Gottlein and T.E.E. Grams. 2005. Competition increasingly dominates the responsiveness of juvenile beech and spruce to elevated $\mathrm{CO}_{2}$ and $/$ or $\mathrm{O}_{3}$ concentrations throughout two subsequent growing seasons. Global Change Biol. 11: 1387-1401.

Kume, A., T. Satomura, N. Tsuboi, M. Chiwa, Y.T. Hanba, K. Nakane, T. Horikoshi and H. Sakugawa. 2003. Effects of understory vegetation on the ecophysiological characteristics of an overstory pine, Pinus densiflora. Forest Ecol. Manage. 176: 195-203.

Kuppers, B.I.L. 1996. Nitrogen and Rubisco contents in eucalypt canopies as affected by Acacia neighbourhood. Plant Physiol. Biochem. 34: 753-760.

Kuppers, M. 1984. Carbon relations and competition between woody species in a central european hedgerow. 3. Carbon and waterbalance on the leaf level. Oecologia 65: 94-100.

Kuppers, M. 1985. Carbon relations and competition between woody species in a Central European hedgerow. 4. Growth form and partitioning. Oecologia 66: 343-352.

Legare, S., Y. Bergeron and D. Pare. 2002. Influence of forest composition on understory cover in boreal mixedwood forests of western Quebec. Silva Fennica 36: 353-366.

Li, M.H., G. Hoch and C. Körner. 2001. Spatial variability of mobile carbohydrates within Pinus cembra trees at the alpine treeline. Phyton-Annales Rei Botanicae 41: 203-213.

Li, M.H., G. Hoch and C. Körner. 2002. Source/sink removal affects mobile carbohydrates in Pinus cembra at the Swiss treeline. Trees-Structure and Function 16: 331-337.

Li, M.H., W.F. Xiao, P. Shi, S.G. Wang, Y.D. Zhong, X.L. Liu, X.D. Wang, X.H. Cai and Z.M. Shi. 2008a. Nitrogen and carbon source-sink relationships in trees at the Himalayan treelines compared to lower elevations. Plant, Cell Environ. 31: 13771387.

Li, M.H., W.F. Xiao, S.G. Wang, G.W. Cheng, P. Cherubini, X.H. Cai, X.L. Liu, X.D. Wang and W.Z. Zhu. 2008b. Mobile carbohydrates in Himalayan treeline trees I. Evidence for carbon gain limitation but not for growth limitation. Tree Physiol. 28: 12871296.

Linden, M. and E. Agestam. 2003. Increment and yield in mixed and monoculture stands of Pinus sylvestris and Picea abies based on an experiment in southern Sweden. Scandinavian J. Forest Res. 18: $155-162$. 
Lloret, F., J. Penuelas and M. Estiarte. 2005. Effects of vegetation canopy and climate on seedling establishment in Mediterranean shrubland. J. Veg. Sci. 16: 67-76.

Makinen, H. and A. Isomaki. 2004. Thinning intensity and growth of Scots pine stands in Finland. Forest Ecol. Manage. 201: 311325.

Manceur, A.M., G.J. Boland, N.V. Thevathasan and A.M. Gordon. 2009. Dry matter partitions and specific leaf weight of soybean change with tree competition in an intercropping system. Agroforestry Syst. 76: 295-301.

Martindale, W. and R.C. Leegood. 1997. Acclimation of photosynthesis to low temperature in Spinacia oleracea L. 2. Effects of nitrogen supply. J. Exp. Bot. 48: 1873-1880.

Matsushima, M. and S.X. Chang. 2006. Vector analysis of understory competition, $\mathrm{N}$ fertilization, and litter layer removal effects on white spruce growth and nutrition in a 13-year-old plantation. Forest Ecol. Manage. 236: 332-341.

Matsushima, M. and S.X. Chang. 2007. Effects of understory removal, $\mathrm{N}$ fertilization, and litter layer removal on soil $\mathrm{N}$ cycling in a 13-year-old white spruce plantation infested with Canada bluejoint grass. Plant and Soil 292: 243-258.

McDowell, N., J.R. Brooks, S.A. Fitzgerald and B.J. Bond. 2003. Carbon isotope discrimination and growth response of old Pinus ponderosa trees to stand density reductions. Plant Cell Environ. 26: 631-644.

McKenzie, D., C.B. Halpern and C.R. Nelson. 2000. Overstory influences on herb and shrub communities in mature forests of western Washington, USA. Can. J. Forest Res. 30: 1655-1666.

Medhurst, J.L. and C.L. Beadle. 2005. Photosynthetic capacity and foliar nitrogen distribution in Eucalyptus nitens is altered by high-intensity thinning. Tree Physiol. 25: 981-991.

Miller, B.J., P.W. Clinton, G.D. Buchan and A.B. Robson. 1998. Transpiration rates and canopy conductance of Pinus radiata growing with different pasture understories in agroforestry systems. Tree Physiol. 18: 575-582.

Misson, L., C. Vincke and F. Devillez. 2003. Frequency responses of radial growth series after different thinning intensities in Norway spruce (Picea abies (L.) Karst.) stands. Forest Ecol. Manage. 177: 51-63.

Mohammed, G.H., T.L. Noland and R.G. Wagner. 1998. Physiological perturbation in jack pine (Pinus banksiana Lamb.) in the presence of competing herbaceous vegetation. Forest Ecol. Manage. 103: 77-85.

Montgomery, R.A., P.B. Reich and B.J. Palik. 2010. Untangling positive and negative biotic interactions: views from above and below ground in a forest ecosystem. Ecology 91: 3641-3655.

Munguia-Rosas, M.A. and V.J. Sosa. 2008. Nurse plants vs. nurse objects: Effects of woody plants and rocky cavities on the recruitment of the Pilosocereus leucocephalus columnar cactus. Ann. Bot. 101: 175-185.

Nambiar, E.K.S. and R. Sands. 1993. Competition for water and nutrients in forests. Can. J. Forest Res. 23: 1955-1968.

Nambiar, E.K.S. and P.G. Zed. 1980. Influence of weeds on the water potential, nutrient content and growth of young Radiata pine. Australian Forest Res. 10: 279-288.

Nichols, J.D., M. Bristow and J.K. Vanclay. 2006. Mixed-species plantations: Prospects and challenges. Forest Ecol. Manage. 233: 383-390.

O'Brien, M.J., K.L. O'Hara, N. Erbilgin and D.L. Wood. 2007. Overstory and shrub effects on natural regeneration processes in native Pinus radiata stands. Forest Ecol. Manage. 240: 178185.

Oakley, B.B., M.P. North and J.F. Franklin. 2006. Facilitative and competitive effects of a $\mathrm{N}$-fixing shrub on white fir saplings. Forest Ecol. Manage. 233: 100-107.

Oren, R., R.H. Waring, S.G. Stafford and J.W. Barrett. 1987. Twenty-four years of Ponderosa pine growth in relation to canopy leaf area and understory competition. Forest Sci. 33: 538547.

Parker, W.C. and D.C. Dey. 2008. Influence of overstory density on ecophysiology of red oak (Quercus rubra) and sugar maple (Acer saccharum) seedlings in central Ontario shelterwoods. Tree Physiol. 28: 797-804.

Parrotta, J.A. 1999. Productivity, nutrient cycling, and succession in single- and mixed-species plantations of Casuarina equisetifolia, Eucalyptus robusta, and Leucaena leucocephala in Puerto Rico. Forest Ecol. Manage. 124: 45-77.

Perry, M.E.L., W.H. Schacht, G.A. Ruark and J.R. Brandle. 2009. Tree canopy effect on grass and grass/legume mixtures in eastern Nebraska. Agroforestry Syst. 77: 23-35.

Petersen, T.D., M. Newton and S.M. Zedaker. 1988. Influence of Ceanothus velutinus and associated forbs on the water-stress and stemwood production of Douglas-fir. Forest Sci. 34: 333-343.

Ram, J., A. Kumar and J. Bhatt. 2004. Plant diversity in six forest types of Uttaranchal, Central Himalaya, India. Current Sci. 86: 975-978.

Richards, A.E., D.I. Forrester, J. Bauhus and M. Scherer-Lorenzen. 2010. The influence of mixed tree plantations on the nutrition of individual species: a review. Tree Physiol. 30: 1192-1208.

Richards, A.E. and S. Schmidt. 2010. Complementary resource use by tree species in a rain forest tree plantation. Ecol. Appl. 20: 1237-1254.

Roberts, S.D. and C.A. Harrington. 2008. Individual tree growth response to variable-density thinning in coastal Pacific Northwest forests. Forest Ecol. Manage. 255: 2771-2781.

Rothe, A. and D. Binkley. 2001. Nutritional interactions in mixed species forests: a synthesis. Can. J. Forest Res. 31: 1855-1870.

Sagar, R., A.S. Raghubanshi and J.S. Singh. 2008. Comparison of community composition and species diversity of understorey and overstorey tree species in a dry tropical forest of northern India. J. Environ. Manage. 88: 1037-1046.

Sala, A., G.D. Peters, L.R. McIntyre and M.G. Harrington. 2005. Physiological responses of ponderosa pine in western Montana to thinning, prescribed fire and burning season. Tree Physiol. 25: 339-348.

Sands, R. and E.K.S. Nambiar. 1984. Water relations of Pinus radiata in competition with weeds. Can. J. Forest Res. 14: 233237.

Shainsky, L.J., M. Newton and S.R. Radosevich. 1992. Effects of intra-specific and inter-specific competition on root and shoot biomass of young douglas-fir and red alder. Can. J. Forest Res. 22: $101-110$.

Shainsky, L.J. and C.L. Rose. 1995. Effects of competition on the foliar chemistry of young Douglas-fir in monoculture and mixed stands with young red alder. Can. J. Forest Res. 25: 1969-1977.

Silvertown, J. 2004. Plant coexistence and the niche. Trends Ecol. Evol. 19: 605-611.

Simard, S.W., T. Blenner-Hassett and I.R. Cameron. 2004. Pre-commercial thinning effects on growth, yield and mortality in evenaged paper birch stands in British Columbia. Forest Ecol. Manage. 190: 163-178. 
Specht, A. and J. Turner. 2006. Foliar nutrient concentrations in mixed-species plantations of subtropical cabinet timber species and their potential as a management tool. Forest Ecol. Manage. 233: 324-337.

Suzuki, A. 2002. Influence of shoot architectural position on shoot growth and branching patterns in Cleyera japonica. Tree Physiol. 22: 885-890.

Takahashi, K. 1997. Regeneration and coexistence of two subalpine conifer species in relation to dwarf bamboo in the understorey. J. Veg. Sci. 8: 529-536.

Takahashi, K., S. Uemura, J.I. Suzuki and T. Hara. 2003. Effects of understory dwarf bamboo on soil water and the growth of overstory trees in a dense secondary Betula ermanii forest, northern Japan. Ecol. Res. 18: 767-774.

Thelin, G., U. Rosengren, I. Callesen and M. Ingerslev. 2002. The nutrient status of Norway spruce in pure and in mixed-species stands. Forest Ecol. Manage. 160: 115-125.

Tian, D.L., Y.Y. Peng, W.D. Yan, X. Fang, W.X. Kang, G.J. Wang and X.Y. Chen. 2010. Effects of thinning and litter fall removal on fine root production and soil organic carbon content in masson pine plantations. Pedosphere 20: 486-493.

Tremmel, D.C. and F.A. Bazzaz. 1995. Plant architecture and allocation in different neighborhoods - Implications for competitive success. Ecology 76: 262-271.

Tripathi, S.K., A. Sumida, K. Ono, H. Shibata, S. Uemura, K. Takahashi and T. Hara. 2006. The effects of understorey dwarf bamboo (Sasa kurilensis) removal on soil fertility in a Betula ermanii forest of northern Japan. Ecol. Res. 21: 315-320.

Tripathi, S.K., A. Sumida, H. Shibata, S. Uemura, K. Ono and T. Hara. 2005. Growth and substrate quality of fine root and soil nitrogen availability in a young Betula ermanii forest of northern Japan: Effects of the removal of understory dwarf bamboo (Sasa kurilensis). Forest Ecol. Manage. 212: 278-290.

Umeki, K. 1995. Importance of crown position and morphological plasticity in competitive interaction in a population of Xanthium canadense. Ann. Bot. 75: 259-265.

van der Heijden, M.G.A. and T.R. Horton. 2009. Socialism in soil? The importance of mycorrhizal fungal networks for facilitation in natural ecosystems. J. Ecol. 97: 1139-1150.

Vandermeer, J. 1989. The Ecology of Intercropping. Cambridge University Press, New York.

Velazquezmartinez, A., D.A. Perry and T.E. Bell. 1992. Response of aboveground biomass increment, growth efficiency, and foliar nutrients to thinning fertilization, and pruning in young
Douglas-fir plantations in the Central Oregon Cascades. Can. J. Forest Res. 22: 1278-1289.

Wang, X.L., J. Zhao, J.P. Wu, H. Chen, Y.B. Lin, L.X. Zhou and S.L. Fu. 2011. Impacts of understory species removal and/or addition on soil respiration in a mixed forest plantation with native species in southern China. Forest Ecol. Manage. 261: 1053-1060.

Watt, M.S., D. Whitehead, e.g., Mason, B. Richardson and M.O. Kimberley. 2003. The influence of weed competition for light and water on growth and dry matter partitioning of young Pinus radiata, at a dryland site. Forest Ecol. Manage. 183: 363-376.

Weiner, J. and L. Fishman. 1994. Competition and allometry in Kochia scoparia. Ann. Bot. 73: 263-271.

Weiskittel, A.R., L.S. Kenefic, R.S. Seymour and L.M. Phillips 2009. Long-term effects of precommercial thinning on the stem dimensions, form and branch characteristics of red spruce and balsam fir crop trees in Maine, USA. Silva Fennica 43: 397-409.

Wilson, J.B. 1990. Mechanisms of species coexistence - 12 explanations for Hutchinson paradox of the plankton - evidence from New-Zealand plant-communities. New Zealand J. Ecol. 13: 1742

Yildiz, O., K. Cromack, S.R. Radosevich, M.A. Martinez-Ghersa and J.E. Baham. 2011. Comparison of 5th-and 14th-year Douglas-fir and understory vegetation responses to selective vegetation removal. Forest Ecol. Manage. 262: 586-597.

Youngberg, C.T. 1975. Effects of fertilization and thinning on growth of ponderosa-pine. Soil Sci. Soc. Am. J. 39: 137-139.

Zhang, J.Y., G.W. Cheng, F.H. Yu, N. Krauchi and M.H. Li. 2008 Intensity and importance of competition for a grass (Festuca rubra) and a legume (Trifolium pratense) vary with environmental changes. J. Integrative Plant Biol. 50: 1570-1579.

Zhang, J.Y., G.W. Cheng, F.H. Yu, N. Krauchi and M.H. Li. 2009a. Interspecific variations in responses of Festuca rubra and Trifolium pratense to a severe clipping under environmental changes. Biologia 64: 292-298.

Zhang, S.Y., G. Chauret and Q.J. Tong. 2009b. Impact of precommercial thinning on tree growth, lumber recovery and lumber quality in Abies balsamea. Scandinavian J. Forest Res. 24: 425433.

Zhao, J., X.L. Wang, Y.H. Shao, G.L. Xu and S.L. Fu. 2011. Effects of vegetation removal on soil properties and decomposer organisms. Soil Biol. Biochem. 43: 954-960.

Received April 8, 2011 Revised August 28, 2011 Accepted November 25, 2011 